\title{
A Comparison of New Factor Models: Evidence From Turkey
}

\author{
Nesrin ÖZKAN ${ }^{1}$
}

\begin{abstract}
The purpose of this paper to compare the performances of new factor models with the former models in Turkey. In that aim, newly proposed q-factor model and Fama-French five factor model are compared with Fama-French three factor, Carhart four factor and Pástor-Stambaugh factor models. The performance metric is chosen as maximum squared Sharpe ratio which gives a better understanding in comparison of two or more models accordance to Barillas and Shanken (2017). As per the measure of maximum squared Sharpe ratio, the q-factor model outperforms of all between July 2009 and June 2017. After that, Carhart four factor model follows as the second best performing model. It is considered that this result may be due to the portfolio formation frequency of profitability and momentum factors. Thus, it can be inferred that the higher the data frequency, the better the explanatory power of the model. Although Fama-French five factor model is similar to q-factor model, the considerable outperformance of q-factor model can be attributed to the way of factor construction and calculation. Consequently, it seems as though the performance of the model is sensitive to the way of factor construction and calculation.
\end{abstract}

Keywords: q-factor model, Fama-French five factor model, Turkey.

JEL Classification: G12, G14

\section{Introduction}

Fama-French five factor model and the q-factor model bring a new extent to the asset pricing. They both asserted the investment and profitability played crucial roles on unexplained returns but somehow differences. It seems as though they have reached the common point from different aspects. Fama and French (2015) explain the relation between returns, investment and profitability in the light of valuation theory while Hou, Xue and Zhang (2015) describe it by q-theory of investment.

According to Fama and French (2015: 4), there is a conditionality among book-to-market equity ratio (BE/ $M E)$, investment and profitability. In other words, BE/ $M E$, profitability and investments are correlated. When profitability and investment are stable, there occurs a positive relation between book-to-market equity and expected returns. On the other hand, the stocks that have high BE/ME value tend to own low profitability and investment, and vice versa. Hou, Xue and Zhang
(2015: 652) describe the relationship between investment, profitability and stock returns by the means of expected cash flows. When the cost of capital is high, investments fall because the net present value of new investment lowly realizes. High expected profitability with respect to low investment denotes to high cost of capital that helps to stabilize the low net present value of new investment. If it wasn't sufficiently high, firms would increase their capital owing to the high net present value of new investment.

While Fama and French (2015) justify the superiority of five factor model, Hou, Xue and Zhang (2015) put forward the q-factor model is all the better. So that the recent studies focus on the comparison of models both in developed and emerging markets. Koh (2015) compared the performances of Carhart four factor model, Fama-French five factor model and the q-factor model between 1926 and 1967 in the US. stock market. It is asserted that q-factors were better than Fama-French factors. It is further propelled that the q-factors could

\footnotetext{
1nsrozkn@gmail.com
} 
not be captured by Fama-French factors, whereas Fama-French factors could be captured by the $\mathrm{q}$-factor model. Besides that, momentum found the strongest effect with $0.68 \%$ monthly premium. Kang, Kang and Kim (2015) tested the Fama-French three factor model, Fama-French five factor model and q-factor model in the Korean stock market. Non-financial firms are included in the analysis and sample period is chosen between July of 2002 and June of 2015. In construction of profitability factor, quarterly data is used and the authors asserted the quarter-based profitability measure in the q-factor model is far better to capture the variation of average returns. GRS-F statistics and average absolute alpha values are chosen as performance metrics. In the findings of the study, it is emphasized the importance of monthly constructed profitability factor. In addition, it is suggested to further test Fama-French five factor model by modifying the quarter-based profitability factor. Fabozzi, Huang and Wang (2016) compared the performance of the q-factor model with Fama-French five factor model between 1972 and 2013. The premiums for the q-factor model are attained as $0.51 \%, 0.31 \%$, $0.44 \%, 0.57 \%$ for market, firm size, investment and profitability, respectively. The market, firm size, value, investment and profitability premiums are calculated $0.53 \%, 0.23 \%, 0.39 \%, 0.37 \%$ and $0.29 \%$ respectively for Fama-French five factor model. The findings showed that the q-factor model outperformed Fama-French five factor model in the analysis period. Another study conducted by Cooper and Maio (2019) who examined whether conditional multifactor models present better performance than unconditional multifactor models in the US. market. The analysis period is held between 1972 and 2013. In the study, 25 Capital Asset Pricing Model (CAPM) anomalies are determined and then CAPM, Fama-French three factor model, Carhart four factor model, Fama-French five factor model and $\mathrm{q}$-factor models are tested. The main finding is that the conditional models are far better than unconditional models. Furthermore, the q-factor model is mainly superior in explaining momentum and profitability anomalies but Fama-French model is better in value-growth anomalies. It appears as though this dispute will go on for some time. However, it is substantially necessary to determine the better performing models not only for developed markets but also for emerging markets.

The factor models attract considerable attention in Turkey as well. Preliminary literature mostly concentrates on the validity of Fama-French three factor model (Gökgöz, 2008; Arıoglu and Canbaş, 2008; Atakan and
Gökbulut, 2010; Güzeldere and Sarıoğlu, 2012). All those studies evidenced the superity of Fama-French three factor model. On the other hand, few studies are conducted to present the comparative performances of factor models. Aksu and Önder (2003) investigated the validity of Fama-French three factor model by comparing with CAPM between 1993 and 1997. For that purpose, they construct SMB and HML factors by following Fama and French (1993) methodology. The authors found that Fama-French three factor model is superior to CAPM. Unlu (2013) tested the validity of Fama-French three factor, Carhart four factor model and Pástor-Stambaugh models in Borsa Istanbul between 1992 and 2011. The author used GRS-F test in decision of the validity of models but the performance comparison is not conducted in the analysis. Thus, it is concluded that they all are valid models and could be used in Borsa Istanbul. Erdinc (2017) tested CAPM, Fama-French three factor and Fama-French five factor model for the analysis period of 2000 and 2017. The author used non-financial 263 firms in the analysis. GRS-F test and average absolute alpha values are fundamentally used as performance metrics in the determination of best performing model. CAPM showed the lowest absolute alpha value but the model has insignificant GRS-F test value. Fama-French five factor model has been found better than CAPM and Fama-French three factor model. Acaravcı and Karaomer (2018) evaluated the performances of CAPM with Fama-French factor models between 2005 and 2016. For that purpose, they have constructed Fama-French three factor model, Fama-French four factor models (by augmenting profitability factor to three factor model) and Fama-French five factor models. In the study, time series regression method is used and GRS-F test is carried out as a performance metric. The authors asserted the best performing model is Fama-French five factor model of all. On the other hand, the factor premiums are lowly obtained even negative for value factor. Aras, Cam, Zavalsız and Keskin (2018) reinvestigated the comparative success of the models and more specifically whether Fama-French five factor model is better than CAPM, Fama-French three factor model. The authors alleged that the paper overcame the shortcomings of previous studies of Acaravcl and Karaomer (2018) and Erdinc (2017). The analysis is held between January 2005 and June 2017. The regression results present the success of Fama-French five factor model and this is in line with previous literature. Early studies have measured the performance of new Fama-French five factor model thus far, Ozkan (2019) has explored 
the outperformance of the q-factor model in Borsa Istanbul. The model consists of market, size, investment and profitability factors those are taken independent variables in regressions and excess returns are dependent variable. In the analysis, eighteen value-weighted portfolios are constructed by taking the intersections of size, investment and profitability portfolios. The regression results have proved the validity of the new model in Borsa Istanbul between 2009 and 2016.

Since the comparison of new models are quite limited in literature, I intended to compare the performances of Fama-French three factor model (hereafter FF3), Carhart four factor (hereafter C4), Pástor-Stambaugh model (hereafter PS) with new models of Fama- French five factor model (hereafter FF5) and the q-factor model. To the best of my knowledge, this study is being the most comprehensive research for the determination of comparative performances of factor models in Turkey. Moreover, one of the few studies on new asset pricing models that test the performance of the q-factor and Fama-French five factor models together in literature.

The rest of the paper is organized as followings. Section 2 describes the multifactor models and under the subheading of the former models that are considered FF3, C4 and PS factor models are explained. Under the subheading of new models, FF5 factor model and the q-factor models are described in details. The short description of the data set and methodology is given in Section 3. Section 4 provides the analysis results that comprise of descriptive statistics, correlation matrix and regression outcomes. Section 5 is the conclusion that summarizes the main findings, outcomes and the subjects to further examine in the future.

\section{Multifactor Models}

CAPM anomalies paved the way for developing new factor models in asset pricing. In CAPM, the market risk is the sole factor in explaining the average returns. Shortly after CAPM, firm size and book-to market equity ratio are explored and defined as risk factors in explaining the returns by Fama and French (1992, 1993 and 1995). Afterall, additional factors are introduced such as momentum and liquidity. All those factors are cumulatively added to market risk factor and nominated as FF3 factor model, C4 factor model and PS factor models.

\subsection{Former Models: Fama-French Three Factor Model, Carhart Four Factor Model and Pástor- Stambaugh Factor Model}

Fama and French (1992) identified the stocks with low market equity and high book- to-market ratio risky. The investors holding these stocks, bear the additional risk and so that they ought to take extra premium for the compensation of the risk. In Fama-French three factor model, the excess return over risk-free rate is described by market, size and value factors and shown as in regression equation (1):

$$
r_{t}-r_{F, t}=\alpha+\beta\left(r_{M}-r_{F}\right)_{t}+s S M B_{t}+h H M L_{t}+\varepsilon_{t}
$$

$$
\begin{aligned}
& r_{t}-r_{F, t} \quad: \text { The excess return of portfolio over } \\
& \text { the risk-free rate }
\end{aligned}
$$

$H M L_{t} \quad$ :The difference in returns of a portfolio of stocks with high book-to-market ratio and a portfolio of stocks with low book-to-market ratio.

where, $r_{F}$ is the risk-free rate, $r_{M}$ is the market return, $\alpha$ is the intercept, $\beta, s$ and $h$ are factor loadings (coefficients).
SMB factor is the firm capitalization (or market equity) that is calculated by the number of shares outstanding times closing stock price and HML factor is calculated by dividing the value of company's book equity to market equity.

Jegadeesh and Titman (1993) explored the profitability of an investment strategy that is based on steadily selling past loser stocks and holding past winner stocks and which is denominated as momentum. After a while, Carhart (1997) four factor model is introduced by adding momentum factor $\left(W M L_{t}\right)$ to FF3 factor model as given in equation (2).

$$
r_{t}-r_{F, t}=\alpha+\beta\left(r_{M}-r_{F}\right)_{t}+s S M B_{t}+h H M L_{t}+w W M L_{t}+\varepsilon_{\mathrm{t}}
$$


$W M L_{t}$ : The difference in returns of a portfolio of stocks with high prior returns and a portfolio of stocks with low prior returns.

where, $w$ is the additional factor loading.
In the model, momentum factor is calculated in accordance with prior 11-months returns for each stock. The factor is distinctively calculated monthly instead of yearly so that the portfolios are rebalanced each month. In regression equation (3), Pástor-Stambaugh model is shown as seen below:

$$
r_{t}-r_{F, t}=\alpha+\beta\left(r_{M}-r_{F}\right)_{t}+s S M B_{t}+h H M L_{t}+l I L L Q_{t}+\varepsilon_{\mathrm{t}}
$$

$I L L Q_{t} \quad$ : The difference in returns of a portfolio of illiquid stocks and a portfolio of liquid stocks.

where, $l$ is the additional factor loading.

Amihud's illiquidity ratio is commonly used as a proxy of liquidity in literature. Since the investors claim extra premium for holding illiquid stocks, it is provided by Amihud's illiquidity premium. For the calculation of illiquidity, the closing prices and trading volume are used by following the method of Amihud (2002).

\subsection{New Models: The q-Factor Model}

Hou, Xue and Zhang (2015: 651) introduced the $\mathrm{q}$-factor model and explained the excess returns over risk-free rate by market, size, investment and profitability factors as given in equation (4):

$r_{t}-r_{F, t}=\alpha+\beta\left(r_{M}-r_{F}\right)_{t}+\beta_{s} M E_{t}+\beta_{i} I N V_{t}+\beta_{r} R O E_{t}+\varepsilon_{t}$

$M E_{t} \quad$ :The difference in returns of a portfolio of small stocks and a portfolio of big stocks.

$I N V_{t} \quad$ :The difference in returns of a portfolio of low investment stocks and a portfolio of high investment stocks.

$R O E_{t} \quad$ :The difference in returns of a portfolio of high profitability stocks and a portfolio of low profitability stocks.

where $\beta, \beta_{s}, \beta_{i}$ and $\beta_{r}$ are factor loadings.

The authors test the model in the US. market and compare it with FF3 and C4 factor models using the data from 1972 to 2012. In order to determine the explanatory power of models, selected 80 anomaly variables are used that are commonly investigated in international markets. GRS-F statistics is used as a decision criteri for the best performing model. The null hypothesis is rejected at 20 tests in regressions of the q-factor model while 28 tests for FF3 factor model and 24 tests for $\mathrm{C} 4$ factor model. This finding revealed the superiority of q-factor model over FF3 and C4 factor models. Furthermore, the factor premiums are calculated $0.31 \%, 0.58 \%$ and $0.45 \%$ for size, profitability and investment, respectively.

In literature, various income proxies are used as profitability. Hou, Xue and Zhang $(2015,2017)$ used Income Before Extraordinary Items for profitability proxy in their studies. Due to the data availability, I used the Income From Continuing Operations to calculate ROE factor as given below.

$$
R O E=\text { Income From Continuing Operations }_{q-1} /{\text { Book } \text { Value }_{q-2}}
$$

In the model, market, size and investment factors are calculated yearly. Contrary to these factors, ROE factor is calculated based on quarterly data. ROE is achieved by dividing recent-announced quarterly income to previous quarter's book value. To this end, earnings announcement dates are controlled each month and used the most recent data in portfolio formation. The underlying reason of using the latest earnings is to represent the newest information about firm profitability (Hou, Xue and Zhang, 2015: 663). On the other hand, four months gap is given for the portfolio formation in the model. In other words, the time interval between the accounting data and portfolio construction is left four months. In practice, six-month gap is generally preferred to prevent "look-ahead bias" "or maintain the "information effect". By controlling the announcement dates each month, the possible bias is eliminated for the model.

The investment factor (INV) is calculated by taking the change in total assets between two consecutive years as in shown below.

$$
I N V=\left(\text { Total Assets }_{t-1}-\text { Total Assets }_{t-2}\right) / \text { Total Assets }_{t-2}
$$


Finally, size is the number of shares outstanding times closing stock price as being used in FF3 factor model.

\subsection{New Models: Fama-French Five Factor Model}

Fama and French $(2015,2016)$ identified two new factors and added them to three factor model. In addition to market, size and value factors, investment and profitability factors are tacked to the model. In new model, excess returns are explained by five factors as in regression equation (5):

$r_{t}-r_{F, t}=\alpha+\beta\left(r_{M}-r_{F}\right)_{t}+s S M B_{t}+h H M L_{t}+r R M W_{t}+c C M A_{t}+\varepsilon_{t}$

Similar to the q-factor model, the profitability (RMW) and investment (CMA) factors are identified as followings:

$C M A_{t} \quad$ :The difference in returns of a portfolio of low investment stocks and a portfolio of high investment stocks.

$R M W_{t}$ :The difference in returns of a portfolio of high profitability stocks and a portfolio of low profitability stocks.

where, $r$ and $c$ are additional factor loadings.

Fama and French (2015) examine the explanatory power of five factor model in the US. market between the period of 1963 and 2013. The findings revealed that five factor model is better than three factor model. When we take a close look at new factors, we can notice the investment factor is similar to the q-factor model, however profitability is rather different. The operating income is used as the profitability proxy in the model and it is taken from annual accounting data. Thus, RMW factor is constructed yearly and rebalanced on June of each year. The calculation of the factor is as followings:

$R M W=$ Operating Income $_{t-1} /$ Book $_{\text {Value }}$

Since FF5 factor model is the extension of FF3 factor model, $\left(r_{M}-r_{F}\right)$, partially SMB and HML factors are the same, and also CMA factor is similar to the INV factor in the q-factor model. As being FF3 factor model, the gap remains six-months between accounting data and portfolio formation.

\section{Data and Methodology}

This section describes primarily the data used in the analysis, following the construction of the factors and lastly maximum squared Sharpe ratio.

\subsection{Data}

The time series regression approach is used in the analysis by following Hou, Xue and Zhang (2015). The analysis period is chosen between 2009 to 2017 by taking into consideration the data availability. The number of shares outstanding is taken from Central Securities Depository (CSD) Institution website and Borsa Istanbul. The accounting data and earnings announcement dates are from the website of Public Disclosure Platform and the risk-free rate is from the website of Central Bank of the Republic of Turkey. BIST 100 is used as the proxy of market return $\left(r_{M}\right)$ and obtained from Borsa Istanbul. Finally, monthly stock prices are from Borsa Istanbul Datastore and returns are calculated for each month as below:

$$
r_{t}=\frac{p_{t}-p_{t-1}}{p_{t-1}}
$$

where,

$r_{t} \quad$ : stock return of time $\mathrm{t}$

$p_{t} \quad$ : adjusted stock price of time $t$

$p_{t-1}$ : adjusted stock price of time t-1

The analysis has some limitations. Financials and the firms with a negative book equity are excluded from the sample. The earnings announcement dates were controlled in analysis, therefore time period started at 2009 due to the data limitation. The firms with unavailable data are not included in the sample in corresponding period. The firms that went bankruptcy are included in the sample in order to prevent any selection bias².

By following Barillas and Shanken (2017), maximum squared Sharpe ratio of factors is used in comparison of factor models. The maximum squared Sharpe ratio of intercept $\left(S h^{2}(\alpha)\right)$ is formulated as below: ${ }^{3}$

$$
S h^{2}(\alpha)=S h^{2}(\Pi)-S h^{2}(f)
$$

In formulation, if the objective is to minimize the $\operatorname{Sh}^{2}(a)$, it could be reached by maximizing the maximum Sharpe ratio of factors $\left(S h^{2}(f)\right)$.

Finally, the portfolios are structured in Ms. Excel, the regressions are run both in Stata 12 and Eviews 10. Stata 12 is also used for White Test, Durbin-Watson Test and maximum squared Sharpe ratio in the analysis. 


\subsection{Construction of Factors}

For FF3 factor model, SMB and HML factors are constructed by keeping Fama and French (1993) methodology. To this end, each year $t$ of June, the stocks are ranked as per market capitalization and sorted into two size group as Big (B) and Small (S). As a breakpoint of size groups, the median of market capitalization is taken into consideration. For HML, the stocks are sorted by book-to-market ratio and then divided into three groups. The NYSE breakpoints are taken as a reference in determining the groups as \%30 of Low (L), \%40 of Medium (M) and \%30 of High (H). The intersection of two size and three book-to-market groups generate six portfolios (abbreviated as $\mathrm{SL}, \mathrm{SM}, \mathrm{SH}, \mathrm{BL}, \mathrm{BM}, \mathrm{BH}$ ). Each year on June, the portfolios are rebalanced and the value- weighted returns are calculated from July of year $t$ to June of year $t+1$. Afterall SMB and HML factors are attained as shown below.

$$
\begin{gathered}
\mathrm{SMB}=(S L+S M+S H) / 3-(B L+B M+B H) / 3 \\
\mathrm{HML}=(S H+B H) / 2-(S L+B L) / 2
\end{gathered}
$$

The WML factor is constructed in accordance with 11-months prior returns. For month $t$, the cumulative returns are calculated from $\mathrm{t}-11$ to $\mathrm{t}-1$. The cumulative returns are ranked in descending order and break into three groups as \%30 of Winner (W), \%40 of Neutral (N) and \%30 of Loser (L). Then six portfolios (abbreviated as $S_{W_{M L}}, S N, S W_{W_{M L}}, B_{W_{M L}} B N, B W_{W M L}$ ) are formed by taking the intersection of two size and three momen- tum groups. After that, value-weighted returns are calculated and the WML factor is generated as below:

$W M L=\left(S W_{W M L}-S L_{W M L}\right) / 2+\left(B W_{W M L}-B L_{W M L}\right) / 2$

The ILLQ factor is constructed by dividing the absolute returns of the stock to its traded volume. After calculating illiquidity for each, stocks are ranked by ILLQ measure and sorted as \%30 of Low (L), \%40 of Medium (M) and \%30 of High (H). The intersection of two size and three illiquidity groups generate six portfolios (abbreviated as SIL, SIM, SIH, BIL, BIM, BIH).

$$
\operatorname{ILLQ}=(S I H+B I H) / 2-(S I L+B I L) / 2
$$

In the q-factor model, the portfolios are constructed on threefold sort. Thus the intersection of two size portfolios (Small and Big) are taken in conjunction with three investment and three profitability groups that can be represented as " $2 \times 3 \times 3$ ". Each June, the stocks are ranked by market capitalization and sorted as Big (B) and Small (S). Next, the stocks are ranked as per investment and divided into three groups by taking the reference of NYSE breakpoints of \%30-\%40-\%30. The same goes for profitability. The stocks are ranked in descending order in accordance with their profitability values. The top $\% 30$ is nominated High $(\mathrm{H})$, the $\% 30$ of the bottom is Low $(\mathrm{L})$ and $\% 40$ of the middle is Medium (M). By taking the intersection of those groups achieved eighteen portfolios ${ }^{4}$. The profitability is calculated monthly and each month the portfolios are rebalanced.

The size factor (ME) is obtained as below:

$$
\begin{gathered}
\mathrm{S}=(\mathrm{SLL}+\mathrm{SLM}+\mathrm{SLH}+\mathrm{SML}+\mathrm{SMM}+\mathrm{SMH}+\mathrm{SHL}+\mathrm{SHM}+\mathrm{SHH}) / 9 \\
\mathrm{~B}=(\mathrm{BLL}+\mathrm{BLM}+\mathrm{BLH}+\mathrm{BML}+\mathrm{BMM}+\mathrm{BMH}+\mathrm{BHL}+\mathrm{BHM}+\mathrm{BHH}) / 9 \\
\mathrm{ME}=(S-M)
\end{gathered}
$$

The investment INV factor is calculated by subtracting average returns of six low investment portfolios and average returns of six high investment portfolios.

$$
\begin{gathered}
\mathrm{L}=(\mathrm{SLL}+\mathrm{SLM}+\mathrm{SLH}+\mathrm{BLL}+\mathrm{BLM}+\mathrm{BLH}) / 6 \\
\mathrm{H}=(\mathrm{SHL}+\mathrm{SHM}+\mathrm{SHH}+\mathrm{BHL}+\mathrm{BHM}+\mathrm{BHH}) / 6 \\
\mathrm{INV}=(L-H)
\end{gathered}
$$

The profitability factor (ROE) is attained in the same manner of INV factor as followings:

$$
\begin{gathered}
\mathrm{H}=(\mathrm{SLH}+\mathrm{SMH}+\mathrm{SHH}+\mathrm{BLH}+\mathrm{BMH}+\mathrm{BHH}) / 6 \\
\mathrm{~L}=(\mathrm{SLL}+\mathrm{SML}+\mathrm{SHL}+\mathrm{BLL}+\mathrm{BML}+\mathrm{BHL}) / 6 \\
\mathrm{ROE}=(H-L)
\end{gathered}
$$

The portfolios in FF5 factor model are constructed two-fold sort (represented as, $2 \times 3$ ). The RMW factor is calculated yearly and the stocks are ranked as per profitability each June. The NYSE breakpoints accepted as a reference to determine the RMW groups as \%30 of Robust (R), \%40 of Medium (M) and \%30 of Weak (W). After that, the intersection of two size portfolios (created in FF3 model) and three profitability portfolios are taken to form six portfolios and generate RMW factor as seen formula below:

$$
\mathrm{RMW}=(S R+B R) / 2-(S W+B W) / 2
$$

In FF5 factor model, the CMA factor is constructed similar to RMW factor so that it is calculated in the same manner. Next, the stocks are ranked as per investment 
value on June each year. The top $\% 30$ is named Conservative (C), the \%30 of the bottom is Agressive (A) and $\% 40$ of the middle is Medium (M). By taking the intersection of these with two size groups achieved six portfolios and constructed CMA factor as shown followings:

$$
\mathrm{CMA}=(S C+B C) / 2-(S A+B A) / 2
$$

In addition to all, $\mathrm{SMB}_{5}$ is the size factor used in FF5 factor model. It is the average of three SMB factors achieved from the intersections of size with value, investment and profitability portfolios.

\section{Findings}

The main objective of this study is to compare the performance of new factor models and to determine the effective factors on average returns in Turkey.

Table 1 summarizes the descriptive statistics of the factors. It seems like the magnitude of size effect has doubt, because size premium ( $\mathrm{SMB}, \mathrm{SMB}_{5}$ and $\mathrm{ME}$ ) is considerably weak as well as illiquidity. On the other hand, the highest premium is attained by profitability but for ROE not for RMW. RMW premium is only 0.220 whereas it is 1.024 for ROE. Next, the market risk premium comes as the second highest premium of all and WML is the third one.

Three substantial inferences might be deducted from descriptive statistics. The calculation frequency, accounting data used to measure profitability and portfolio construction of profitability factor matter in new models. First, ROE factor is better to capture the average returns related profitability than RMW. While the profitability factor in FF5 (RMW factor) is 0.220 , the ROE factor is 1.024 in the q-factor model. Second is about the momentum factor which is also constructed monthly similar to ROE factor, provides the third highest premium. That may indicate more on the importance of calculation frequency of factors. Third is about the investment factors in FF5 factor and q-factor model. The CMA premium is attained only 0.253 while INV factor is 0.546 . So that recall the Hou, Xue and Zhang (2015) who emphasize the crucial importance on the construction of factors. Hou, Xue and Zhang (2015) asserted that there was a conditionality between profitability and investment thus the portfolios ought to be formed three-fold sort in order to control both effects. Table 2 reports the correlations among the factors.

Table 1: Descriptive Statistics

\begin{tabular}{lccccccccccccc}
\hline & MKT & SMB & HML WML ILLQ & SMB & CMA & RMW & ME & \multicolumn{2}{c}{ INV } & ROE \\
\hline Mean (\%) & 0.972 & 0.062 & 0.497 & 0.550 & -0.174 & 0.166 & 0.253 & 0.220 & 0.116 & 0.546 & 1.024 \\
Standard Err. & 0.007 & 0.004 & 0.005 & 0.004 & 0.012 & 0.003 & 0.003 & 0.004 & 0.003 & 0.003 & 0.003 \\
Median & 0.006 & -0.001 & 0.006 & 0.008 & 0.002 & 0.001 & 0.000 & 0.004 & 0.000 & 0.003 & 0.007 \\
Minimum & -0.138 & -0.119 & -0.294 & -0.131 & -0.922 & -0.104 & -0.084 & -0.096 & -0.085 & -0.093 & -0.072 \\
Maximum & 0.160 & 0.209 & 0.184 & 0.103 & 0.342 & 0.154 & 0.156 & 0.152 & 0.091 & 0.173 & 0.078 \\
Count & 96 & 96 & 96 & 96 & 96 & 96 & 96 & 96 & 96 & 96 & 96 \\
\hline
\end{tabular}

Table 2: Correlation Matrix of Factors

\begin{tabular}{lccccccccccc}
\hline \multicolumn{1}{c}{ MKT } & SMB & HML WML ILLQ & SMB & CMA & RMW & ME & INV & ROE \\
\hline MKT & 1.000 & & & & & & & & & & \\
SMB & -0.045 & 1.000 & & & & & & & & & \\
HML & -0.007 & -0.631 & 1.000 & & & & & & & & \\
WML & -0.178 & -0.019 & -0.097 & 1.000 & & & & & & & \\
ILLQ & -0.042 & -0.168 & 0.275 & -0.070 & 1.000 & & & & & & \\
SMB 5 & -0.067 & 0.980 & -0.503 & -0.021 & -0.147 & 1.000 & & & & & \\
CMA & 0.020 & 0.503 & -0.393 & 0.012 & 0.286 & 0.456 & 1.000 & & & & \\
RMW & -0.020 & -0.341 & 0.423 & -0.311 & 0.250 & -0.316 & -0.066 & 1.000 & & & \\
ME & -0.077 & 0.509 & 0.096 & 0.103 & -0.017 & 0.612 & 0.019 & -0.201 & 1.000 & & \\
INV & 0.054 & 0.454 & -0.363 & -0.031 & 0.234 & 0.414 & 0.834 & -0.060 & 0.052 & 1.000 & \\
ROE & -0.287 & -0.271 & 0.103 & 0.214 & -0.122 & -0.238 & -0.266 & 0.120 & 0.077 & -0.097 & 1.000 \\
\hline
\end{tabular}


Fama and French (1995) showed BE/ME, profitability and investments are highly correlated (Fama and French, 2015: 4). In the light of this statement, high $\mathrm{BE} / \mathrm{ME}$ stocks tend to high profitability and aggressive investment. However, the correlation between factors does not represent such relations in the analysis. The correlation among size factors ( $\mathrm{SMB}, \mathrm{SMB}_{5}$ and $\mathrm{ME}$ ) and investment factors (CMA and INV) are quite usual. Except for corresponding factors, no multicollinearity is detected among the others.
Table 3, 4, 5, 6, 7 shows the regression results of factor models. In tables, $\alpha$ represents intercept $\beta$, $s, h, w, l, r, c, \beta_{s}, \beta_{i}$ and, $\beta_{r}$, are factor loadings. $\mathrm{F}$, Adj. $R^{2}, D W$ and White Test denote $F$ statistics, adjusted $\mathrm{R}^{2}$, Durbin-Watson statistics and White test statistics, respectively. The values below a represent the standard errors, the values below factor loadings are t-statistics and further the values below White test statistics are p-values.

Table 3: Fama-French Three Factor Model

\begin{tabular}{ccccccccc}
\hline $\mathbf{r}-\mathbf{r}_{\mathbf{F}}$ & $\boldsymbol{\alpha}$ & $\boldsymbol{\beta}$ & $\mathbf{s}$ & $\mathbf{h}$ & $\mathbf{F}$ & $\mathbf{A d j .} \mathbf{R}^{2}$ & $\mathbf{D W}$ & White Test \\
\hline SL & 0.012 & $0.801^{*}$ & $1.438^{*}$ & $-0.583^{* * *}$ & 80.822 & 0.715 & 1.749 & 74.468 \\
& $\mathbf{0 . 0 0 7}$ & $\mathbf{1 1 . 8 3 2}$ & $\mathbf{6 . 7 9 4}$ & $\mathbf{- 1 . 6 8 4}$ & & & & $\mathbf{0 . 0 0 0}$ \\
$\mathbf{S M}$ & 0.007 & $0.741^{*}$ & $1.117^{*}$ & $0.417^{*}$ & 96.296 & 0.750 & 2.012 & 12.448 \\
& $\mathbf{0 . 0 0 3}$ & $\mathbf{1 4 . 3 4 0}$ & $\mathbf{9 . 7 6 8}$ & $\mathbf{4 . 5 8 8}$ & & & & $\mathbf{0 . 1 8 9}$ \\
SH & 0.008 & $0.759^{*}$ & $1.110^{*}$ & $0.529 *$ & 91.692 & 0.741 & 2.212 & 8.613 \\
& $\mathbf{0 . 0 0 4}$ & $\mathbf{1 4 . 2 2 5}$ & $\mathbf{9 . 4 0 3}$ & $\mathbf{5 . 6 2 9}$ & & & & $\mathbf{0 . 4 7 3}$ \\
$\mathbf{B L}$ & 0.007 & $0.747 *$ & 0.016 & $-0.286^{*}$ & 83.238 & 0.721 & 2.109 & 22.205 \\
& $\mathbf{0 . 0 0 3}$ & $\mathbf{1 3 . 3 4 4}$ & $\mathbf{0 . 1 4 2}$ & $\mathbf{- 2 . 4 3 9}$ & & & & $\mathbf{0 . 0 0 8}$ \\
$\mathbf{B M}$ & 0.008 & $0.765^{*}$ & $0.305^{*}$ & 0.049 & 61.254 & 0.656 & 2.028 & 10.826 \\
& $\mathbf{0 . 0 0 4}$ & $\mathbf{1 3 . 3 9 0}$ & $\mathbf{2 . 4 0 9}$ & $\mathbf{0 . 4 8 8}$ & & & & $\mathbf{0 . 2 8 7}$ \\
$\mathbf{B H}$ & 0.011 & $0.789^{*}$ & $0.344^{* * *}$ & $0.601 * * *$ & 36.984 & 0.531 & 1.776 & 71.566 \\
& $\mathbf{0 . 0 0 6}$ & $\mathbf{1 2 . 0 4 3}$ & $\mathbf{1 . 8 3 2}$ & $\mathbf{1 . 9 7 7}$ & & & & $\mathbf{0 . 0 0 0}$ \\
\hline
\end{tabular}

${ }^{*},{ }^{* *}$ and ${ }^{* * *}$ denote the statistical significance at the of $\% 1, \% 5$ and $\% 10$ levels, respectively.

Table 4: Carhart Four Factor Model

\begin{tabular}{|c|c|c|c|c|c|c|c|c|c|}
\hline $\mathbf{r}-\mathbf{r}_{\mathbf{F}}$ & $\alpha$ & $\beta$ & $\mathbf{s}$ & $\mathbf{h}$ & $\mathbf{w}$ & $\mathbf{F}$ & Adj. $\mathbf{R}^{2}$ & DW & White Test \\
\hline \multirow[t]{2}{*}{ SL } & 0.016 & $0.746^{*}$ & $1.361^{*}$ & $-0.663 * *$ & -0.552 & 70.946 & 0.746 & 1.875 & 75.214 \\
\hline & 0.007 & 10.987 & 6.097 & -2.345 & -1.627 & & & & 0.000 \\
\hline \multirow[t]{2}{*}{ SM } & 0.007 & $0.738^{*}$ & $1.112 *$ & $0.412^{*}$ & -0.036 & 71.574 & 0.748 & 2.001 & 37.106 \\
\hline & 0.003 & 10.962 & 9.769 & 5.079 & -0.261 & & & & 0.001 \\
\hline \multirow[t]{2}{*}{ SH } & 0.009 & $0.739^{*}$ & $1.083^{*}$ & $0.501^{*}$ & -0.198 & 72.042 & 0.749 & 2.235 & 31.516 \\
\hline & 0.003 & 13.332 & 9.093 & 4.604 & -1.384 & & & & 0.005 \\
\hline \multirow[t]{2}{*}{ BL } & 0.008 & $0.730^{*}$ & -0.006 & $-0.309^{*}$ & -0.164 & 64.722 & 0.728 & 2.113 & 36.514 \\
\hline & 0.003 & 13.209 & -0.048 & -2.558 & -1.308 & & & & 0.001 \\
\hline \multirow[t]{2}{*}{ BM } & 0.009 & 0.755 & 0.290 & 0.034 & -0.104 & 46.140 & 0.655 & 2.011 & 50.100 \\
\hline & 0.003 & 0.063 & 0.125 & 0.104 & 0.168 & & & & 0.000 \\
\hline \multirow[t]{2}{*}{ ВH } & 0.014 & $0.737^{*}$ & 0.272 & $0.526^{* *}$ & -0.518 & 34.589 & 0.585 & 1.911 & 79.453 \\
\hline & 0.005 & 11.428 & 1.363 & 2.227 & -1.658 & & & & 0.000 \\
\hline \multirow[t]{2}{*}{$\mathbf{S L}_{\text {WML }}$} & 0.009 & $0.807^{*}$ & $1.117^{*}$ & $0.328^{*}$ & $-0.452 *$ & 87.610 & 0.784 & 2.299 & 25.614 \\
\hline & 0.003 & 15.316 & 7.628 & 2.985 & -3.707 & & & & 0.029 \\
\hline \multirow[t]{2}{*}{$\mathbf{S W}_{\text {WML }}$} & 0.005 & $0.759^{*}$ & $0.885^{*}$ & $0.354^{*}$ & $0.375^{* *}$ & 48.464 & 0.666 & 2.028 & 34.639 \\
\hline & 0.004 & 11.993 & 5.233 & 2.868 & 2.111 & & & & 0.002 \\
\hline \multirow[t]{2}{*}{$B L_{W M L}$} & 0.006 & $0.740^{*}$ & 0.187 & 0.097 & -0.847 & 53.480 & 0.688 & 1.876 & 69.162 \\
\hline & 0.005 & 12.002 & 0.845 & 0.845 & 0.438 & & & & 0.000 \\
\hline \multirow[t]{2}{*}{ BW $_{\text {WML }}$} & 0.012 & $0.788^{*}$ & $0.419^{*}$ & 0.070 & $0.324 * * *$ & 41.679 & 0.631 & 2.217 & 50.437 \\
\hline & 0.004 & 12.814 & 2.876 & 0.658 & 1.769 & & & & 0.000 \\
\hline
\end{tabular}

$*, \overline{* *}$ and ${ }^{* * *}$ denote the statistical significance at the of $\% 1, \% 5$ and $\% 10$ levels, respectively. 
In Table 3, F statistic presents the general significance of the model. All the coefficients have almost $\% 1$ significance level. White and Durbin-Watson test statistics are used to determine the presence of autocorrelation and heteroscedasticity. White test points out heteroscedasticity problem for SL, BL and $\mathrm{BH}$ regression models. Thus, the standard errors are corrected by Newey-West HAC and adjusted t-statistics are reported in the table.

In Table 4, alpha values, coefficients, F-values, adjusted $R^{2}$ values, Durbin-Watson and White test statistics are presented for Carhart four factor model. The coefficients for market, size and value are generally significant at $1 \%$ level. For momentum, they seem low especially for the intersection of size and value portfolios. On the other hand, they are found high for size and momentum portfolios. When we consider the $F$ values, the significance of models is stable. In regression models, all t-statistics are corrected against autocorrelation and heteroscedasticity.

Table 5 presents the regression results for Pástor-Stambaugh model. The t-statistics are corrected owing to the heteroscedasticity in the models. The betas are found significant at $1 \%$ level. The coefficients are only significant for SIL and BIL portfolios used in the construction of illiquidity factor. The adjusted $R^{2}$ values range between 0.924 and 0.382 . The average of adjusted $R^{2}$ values is calculated 0.692 and it implies the changes in dependent variable is $69 \%$ explained by the factors in the model. When adjusted $R^{2}$ values are compared with FF3 and C4 factor models, it is observed that all those values are close to each other.

Table 5: Pástor-Stambaugh Model

\begin{tabular}{|c|c|c|c|c|c|c|c|c|c|}
\hline $\mathbf{r}-\mathbf{r}_{\mathrm{F}}$ & $\alpha$ & $\boldsymbol{\beta}$ & $\mathbf{s}$ & h & 1 & $\mathbf{F}$ & Adj. $R^{2}$ & DW & White Test \\
\hline \multirow[t]{2}{*}{ SL } & 0.012 & $0.800^{*}$ & $1.438^{*}$ & -0.573 & -0.014 & 60.023 & 0.713 & 1.740 & 83.102 \\
\hline & 0.007 & 11.651 & 6.736 & -1.507 & -0.232 & & & & 0.000 \\
\hline \multirow[t]{2}{*}{ SM } & 0.007 & $0.737^{*}$ & $1.118^{*}$ & $0.456^{*}$ & $-0.058 * * *$ & 75.315 & 0.757 & 2.020 & 15.904 \\
\hline & 0.003 & 14.461 & 9.923 & 4.967 & -1.935 & & & & 0.319 \\
\hline \multirow[t]{2}{*}{ SH } & 0.008 & $0.757^{*}$ & $1.111^{*}$ & $0.545^{*}$ & -0.023 & 68.560 & 0.739 & 2.196 & 11.137 \\
\hline & 0.004 & 14.147 & 9.383 & 5.639 & -0.734 & & & & 0.675 \\
\hline \multirow[t]{2}{*}{ BL } & 0.007 & $0.744^{*}$ & 0.018 & $-0.255^{* *}$ & $-0.045^{*}$ & 63.996 & 0.726 & 2.106 & 29.615 \\
\hline & 0.003 & 13.632 & 0.141 & -2.170 & -2.486 & & & & 0.009 \\
\hline \multirow[t]{2}{*}{ BM } & 0.008 & $0.765^{*}$ & $0.305^{*}$ & 0.059 & -0.014 & 45.581 & 0.652 & 2.013 & 22.362 \\
\hline & 0.004 & 13.302 & 2.400 & 0.569 & -0.432 & & & & 0.072 \\
\hline \multirow[t]{2}{*}{ BH } & 0.011 & $0.787^{*}$ & $0.344 * * *$ & $0.625^{* * *}$ & -0.036 & 27.747 & 0.529 & 1.757 & 83.760 \\
\hline & 0.006 & 12.030 & 1.793 & 1.853 & -0.641 & & & & 0.000 \\
\hline \multirow[t]{2}{*}{ SIL } & 0.011 & $0.547^{*}$ & $1.557^{*}$ & $0.474 * *$ & $-1.817^{*}$ & 293.22 & 0.924 & 2.422 & 62.372 \\
\hline & 0.005 & 5.433 & 4.704 & 2.075 & -13.949 & & & & 0.000 \\
\hline \multirow[t]{2}{*}{ SIH } & 0.008 & $0.775^{*}$ & $1.076^{*}$ & $0.448^{*}$ & 0.015 & 77.252 & 0.762 & 2.129 & 10.360 \\
\hline & 0.003 & 15.258 & 9.585 & 4.892 & 0.524 & & & & 0.735 \\
\hline \multirow[t]{2}{*}{ BIL } & 0.005 & $0.834^{*}$ & 0.144 & 0.159 & $-0.071 * * *$ & 65.669 & 0.731 & 2.149 & 64.002 \\
\hline & 0.004 & 18.774 & 1.281 & 1.081 & -1.948 & & & & 0.000 \\
\hline \multirow[t]{2}{*}{ BIH } & 0.008 & $0.607 *$ & $0.625^{*}$ & 0.185 & 0.095 & 15.694 & 0.382 & 2.266 & 57.135 \\
\hline & 0.005 & 6.929 & 2.389 & 0.925 & 0.985 & & & & 0.000 \\
\hline
\end{tabular}


Table 6: Fama-French Five Factor Model

\begin{tabular}{|c|c|c|c|c|c|c|c|c|c|c|}
\hline $\mathbf{r}-\mathbf{r}_{\mathbf{F}}$ & $\alpha$ & $\beta$ & $\mathbf{s}$ & h & $\mathbf{r}$ & c & $\mathbf{F}$ & Adj. $R^{2}$ & DW & White Test \\
\hline \multirow[t]{2}{*}{ SL } & 0.010 & $0.805^{*}$ & $1.278^{*}$ & $-0.844^{*}$ & 0.212 & 0.347 & 44.208 & 0.694 & 1.777 & 87.985 \\
\hline & 0.006 & 10.437 & 7.686 & -2.599 & 0.539 & 0.860 & & & & 0.000 \\
\hline \multirow[t]{2}{*}{ SM } & 0.006 & $0.748^{*}$ & $1.134 *$ & $0.288^{*}$ & -0.107 & 0.007 & 57.042 & 0.746 & 2.087 & 29.458 \\
\hline & 0.003 & 14.320 & 8.832 & 3.203 & -1.018 & 0.056 & & & & 0.079 \\
\hline \multirow[t]{2}{*}{ SH } & 0.007 & $0.759^{*}$ & $0.992 *$ & $0.422 *$ & -0.120 & $0.274 * * *$ & 51.240 & 0.725 & 2.300 & 30.444 \\
\hline & 0.004 & 13.767 & 7.314 & 4.448 & -1.079 & 1.935 & & & & 0.063 \\
\hline \multirow[t]{2}{*}{ BL } & 0.007 & $0.743 *$ & -0.028 & $-0.234^{*}$ & -0.169 & 0.062 & 51.040 & 0.724 & 2.198 & 33.979 \\
\hline & 0.003 & 13.217 & -0.239 & -2.926 & -1.360 & 0.448 & & & & 0.026 \\
\hline \multirow[t]{2}{*}{ BM } & 0.007 & $0.758^{*}$ & 0.134 & 0.038 & -0.060 & $0.313^{* *}$ & 37.245 & 0.656 & 2.158 & 26.484 \\
\hline & 0.004 & 13.235 & 0.953 & 0.391 & -0.523 & 2.128 & & & & 0.150 \\
\hline \multirow[t]{2}{*}{ BH } & 0.011 & $0.789 *$ & $0.257^{* * *}$ & $0.498 * * *$ & 0.162 & 0.135 & 21.788 & 0.522 & 1.804 & 90.450 \\
\hline & 0.005 & 11.105 & 1.862 & 1.847 & 0.476 & 0.392 & & & & 0.000 \\
\hline \multirow[t]{2}{*}{ SR } & 0.010 & $0.760^{*}$ & $1.151^{*}$ & -0.001 & 0.121 & $0.808^{*}$ & 62.111 & 0.762 & 2.064 & 78.971 \\
\hline & 0.004 & 12.467 & 9.409 & -0.002 & 0.533 & 3.498 & & & & 0.000 \\
\hline \multirow[t]{2}{*}{ SW } & 0.007 & $0.739^{*}$ & $1.158^{*}$ & 0.025 & -0.041 & $-0.462 * *$ & 45.195 & 0.699 & 1.968 & 33.773 \\
\hline & 0.004 & 10.616 & 8.793 & 0.251 & -0.365 & -2.243 & & & & 0.027 \\
\hline \multirow[t]{2}{*}{$\mathbf{B R}$} & 0.007 & $0.748^{*}$ & 0.153 & 0.040 & -0.043 & $0.441 * *$ & 34.894 & 0.640 & 2.070 & 36.867 \\
\hline & 0.004 & 10.185 & 0.965 & 0.409 & -0.313 & 2.089 & & & & 0.012 \\
\hline \multirow[t]{2}{*}{ B W } & 0.010 & $0.770^{*}$ & 0.146 & 0.015 & 0.119 & -0.288 & 28.821 & 0.594 & 2.053 & 79.938 \\
\hline & 0.004 & 11.441 & 1.029 & 0.079 & 0.465 & -1.197 & & & & 0.000 \\
\hline \multirow[t]{2}{*}{ SC } & 0.004 & $0.807^{*}$ & $1.042 *$ & $0.414^{*}$ & -0.335 & 0.28 & 51.148 & 0.725 & 2.056 & 52.051 \\
\hline & 0.003 & 12.223 & 8.142 & 3.934 & -1.579 & 1.548 & & & & 0.000 \\
\hline \multirow[t]{2}{*}{ SA } & 0.110 & $0.672 *$ & $0.938^{*}$ & 0.002 & 0.040 & -0.227 & 24.753 & 0.555 & 1.970 & 46.922 \\
\hline & 0.005 & 9.787 & 4.455 & 0.025 & 0.310 & -0.836 & & & & 0.001 \\
\hline \multirow[t]{2}{*}{ BC } & 0.004 & $0.837^{*}$ & 0.220 & 0.184 & 0.186 & 0.072 & 18.578 & 0.480 & 1.698 & 89.879 \\
\hline & 0.006 & 9.314 & 1.320 & 0.902 & 0.511 & 0.202 & & & & 0.000 \\
\hline \multirow[t]{2}{*}{$\mathbf{B A}$} & 0.010 & $0.769^{*}$ & -0.142 & $-0.147 * * *$ & -0.156 & 0.032 & 49.572 & 0.718 & 2.386 & 29.312 \\
\hline & 0.003 & 15.244 & -1.151 & -1.691 & -1.532 & 0.250 & & & & 0.081 \\
\hline
\end{tabular}

${ }^{*},{ }^{* *}$ and ${ }^{* *}$ denote the statistical significance at the of $\% 1, \% 5$ and $\% 10$ levels, respectively.

Table 6 shows the regression results of Fama-French five factor model. The beta coefficients are found significant at \%1 level. The factor loadings for size, value, investment and profitability are not as significant as beta. White and Durbin-Watson test statistics exhibit the autocorrelation and heteroscedasticity in regressi- on models, for that reason t-statistics are corrected and reported the corrected values in the table. The F statistic that presents the overall significance of the regression model, verify that the model is statistically significant. The average of adjusted $R^{2}$ values calculated nearly $66 \%$. 
Table 7: The q-factor Model

\begin{tabular}{|c|c|c|c|c|c|c|c|c|c|}
\hline $\mathbf{r}-\mathbf{r}_{\mathbf{F}}$ & $\alpha$ & $\beta$ & $\boldsymbol{\beta}_{\mathrm{s}}$ & $\beta_{1}$ & $\beta_{\mathbf{r}}$ & $\mathbf{F}$ & Adj. $R^{2}$ & DW & White Test \\
\hline \multirow{2}{*}{ SLL } & 0.014 & $0.678^{*}$ & $0.697 *$ & $0.342^{*}$ & $-0.749 *$ & 56.427 & 0.700 & 2.060 & 18.552 \\
\hline & 0.004 & 10.377 & 5.225 & 2.760 & -5.955 & & & & 0.182 \\
\hline \multirow[t]{2}{*}{ SLM } & 0.015 & $0.621^{*}$ & $0.834^{*}$ & $0.582^{*}$ & $-0.551^{*}$ & 34.978 & 0.588 & 1.838 & 40.540 \\
\hline & 0.005 & 9.229 & 3.425 & 2.854 & -4.216 & & & & 0.000 \\
\hline \multirow[t]{2}{*}{ SLH } & 0.014 & $0.637^{*}$ & $1.103^{*}$ & 0.445 & $0.364 * * *$ & 18.634 & 0.426 & 2.039 & 41.988 \\
\hline & 0.006 & 7.009 & 4.052 & 1.548 & 1.660 & & & & 0.001 \\
\hline \multirow[t]{2}{*}{ SML } & 0.016 & $0.761^{*}$ & $0.775^{*}$ & 0.341 & $-0.956^{*}$ & 29.520 & 0.545 & 2.263 & 41.236 \\
\hline & 0.005 & 8.032 & 2.780 & 0.871 & -3.643 & & & & 0.001 \\
\hline \multirow[t]{2}{*}{ SMM } & 0.012 & $0.674^{*}$ & $0.770^{*}$ & 0.123 & $-0.451^{*}$ & 32.624 & 0.571 & 2.258 & 42.066 \\
\hline & 0.004 & 9.297 & 3.840 & 0.471 & -3.316 & & & & 0.000 \\
\hline \multirow[t]{2}{*}{ SMH } & 0.005 & $0.781^{*}$ & $0.648^{*}$ & 0.153 & 0.224 & 23.658 & 0.488 & 1.918 & 37.920 \\
\hline & 0.005 & 8.976 & 2.948 & 0.528 & 1.060 & & & & 0.000 \\
\hline \multirow[t]{2}{*}{ SHL } & 0.013 & $0.768^{*}$ & $0.598^{*}$ & 0.030 & $-0.915^{*}$ & 37.711 & 0.607 & 2.248 & 36.715 \\
\hline & 0.004 & 9.103 & 2.429 & 0.094 & -5.956 & & & & 0.000 \\
\hline \multirow[t]{2}{*}{ SHM } & 0.011 & $0.483^{*}$ & $0.740^{*}$ & -0.088 & $-0.386^{*}$ & 12.628 & 0.328 & 1.689 & 29.702 \\
\hline & 0.006 & 5.019 & 3.555 & -0.303 & -2.488 & & & & 0.008 \\
\hline \multirow[t]{2}{*}{ SHH } & 0.010 & $0.699 *$ & $0.789 * * *$ & -0.273 & 0.117 & 13.719 & 0.348 & 2.119 & 68.853 \\
\hline & 0.005 & 8.961 & 1.886 & -0.535 & 0.540 & & & & 0.000 \\
\hline \multirow[t]{2}{*}{ BLL } & 0.007 & $0.734^{*}$ & -0.104 & 0.366 & $-0.681^{*}$ & 35.911 & 0.595 & 1.800 & 30.635 \\
\hline & 0.005 & 8.551 & -0.579 & $1.682 * * *$ & -5.143 & & & & 0.006 \\
\hline \multirow[t]{2}{*}{ BLM } & 0.019 & $0.593^{*}$ & -1.102 & $2.162 * * *$ & $-0.543 * * *$ & 19.610 & 0.439 & 1.962 & 93.935 \\
\hline & 0.008 & 4.948 & -1.444 & 1.767 & -1.728 & & & & 0.000 \\
\hline \multirow[t]{2}{*}{ BLH } & 0.011 & $0.682 *$ & 0.139 & $0.362^{*}$ & -0.176 & 33.640 & 0.578 & 2.112 & 21.027 \\
\hline & 0.004 & 10.124 & 1.015 & 2.828 & -1.360 & & & & 0.100 \\
\hline \multirow[t]{2}{*}{ BML } & 0.007 & $0.597 *$ & -0.002 & -0.107 & $-0.916^{*}$ & 27.659 & 0.528 & 1.780 & 7.002 \\
\hline & 0.005 & 6.965 & -0.012 & -0.662 & -5.549 & & & & 0.934 \\
\hline \multirow[t]{2}{*}{ ВMМ } & 0.010 & $0.727^{*}$ & -0.001 & $0.217^{* * *}$ & -0.087 & 36.200 & 0.597 & 1.966 & 12.615 \\
\hline & 0.004 & 11.061 & -0.010 & 1.737 & -0.690 & & & & 0.557 \\
\hline \multirow[t]{2}{*}{ ВМН } & 0.010 & $0.773^{*}$ & $-0.408^{* * *}$ & 0.065 & 0.252 & 23.726 & 0.488 & 2.139 & 34.339 \\
\hline & 0.002 & 10.962 & -1.758 & 0.527 & 0.867 & & & & 0.001 \\
\hline \multirow[t]{2}{*}{ BHL } & 0.006 & $0.732^{*}$ & 0.210 & -0.253 & $-0.896^{*}$ & 28.199 & 0.533 & 2.058 & 36.304 \\
\hline & 0.006 & 8.537 & 0.639 & -0.862 & -4.033 & & & & 0.000 \\
\hline \multirow[t]{2}{*}{ ВНМ } & 0.029 & $0.564^{*}$ & -0.672 & $-1.120^{* * *}$ & -0.359 & 10.931 & 0.294 & 1.688 & 80.450 \\
\hline & 0.012 & 4.453 & -1.322 & -1.691 & -1.595 & & & & 0.000 \\
\hline \multirow[t]{2}{*}{ ВHH } & 0.012 & $0.699 *$ & -0.097 & -0.032 & 0.102 & 31.306 & 0.560 & 1.986 & 24.107 \\
\hline & 0.003 & 9.981 & -0.694 & -0.206 & 0.845 & & & & 0.044 \\
\hline
\end{tabular}

${ }^{*}, * *$ and ${ }^{* * *}$ denote the statistical significance at the of $\% 1, \% 5$ and $\% 10$ levels, respectively.

The regression results of the $\mathrm{q}$-factor model are tabulated in Table 7. Similar to previous models, the beta coefficients are found significant at $1 \%$ level. F statistics have proved the overall significance of the model. The 
significance of size, investment and profitability factor loadings are obtained higher vis-à-vis Fama-French five factor model. That may stem from the distinction of two models in portfolio construction and factor calculation. Besides that, it could be counted as the preliminary evidence that new models are sensitive to the way of factors calculated and constructed. In order to obtain further evidence, the comparison analysis is run for the models.

Table 8: Comparison of Factor Models as per Maximum Squared Sharpe Ratio

\begin{tabular}{lc}
\hline \multicolumn{1}{c}{ Factor Models } & $\mathbf{S h}^{2}$ (f) \\
\hline Fama-French Three Factor Model & 0.0481 \\
Carhart Four Factor Model & 0.0942 \\
Pastor-Stambaugh Four Factor Model & 0.0498 \\
Fama- French Five Factor Model & 0.0626 \\
q-factor Model & 0.1697 \\
\hline
\end{tabular}

The performance of the models is evaluated as per the maximum squared Sharpe ratio and shown all in Table 8. In order to compare and interpret the values, we should keep in mind that the higher the Sharpe ratio is, the better is the performance of the model. When we rank the metrics in ascending order, the q-factor model comes first and then Carhart four factor model, Fama-French five factor model, Pástor-Stambaugh factor model and Fama-French three factor model, respectively. The maximum squared Sharpe ratio is almost 0.063 for Fama-French five factor model whereas it is nearly 0.170 for the q-factor model. The difference between them is about 0.107 and which matters a lot in the comparison of the values.

In light of all results, it is concluded that the q-factor model outperforms of all. This result is in line with Hou, Xue and Zhang (2017). In analysis, the q-factor model is found far better to capture the unexplained returns related to profitability and investment in comparison to Fama-French five factor model. In the study of Kang, Kang and Kim (2015), it is emphasized how important is to construct the profitability factor based on quarterly data. For this study, the findings exhibit the success of ROE premium which is found 1.024 whereas RMW is 0.220 monthly. In addition to that, the highest premium is attained for ROE profitability similar to Kang, Kang and Kim (2015). Since the performance of Carhart four factor model comes second, it is contemplated the effect of calculation frequency of factors. The momen- tum and profitability factors are calculated monthly so they may capture the variation of cross-section of returns better. Besides that, the outperformance of the q-factor model in comparison with Fama-French five factor model strengthens the findings.

\section{Conclusion}

In this study, the comparative performances of new factor models are primarily investigated and it is further searched whether the q-factor model performs better than Fama-French five factor model in Turkey. The sample covers all stocks in BIST Main market. The analysis is held for eight years from 2009 to 2017 due to data unavailability of earnings announcement dates. The time series regressions are used in factor models. The main comparison metric is taken as the maximum squared Sharpe ratio by

following Barillas and Shanken (2017).

The results showed that the q-factor model performs better than FF5 factor model as well as FF3, C4 and PS factor models. In other words, the common variation of stock returns is relatively better captured by the $\mathrm{q}$-factor model. Despite the $\mathrm{q}$-factor model and FF5 factor model include almost the same factors or they are closely related, the evidences present that the portfolio construction method and factor calculations are sensitive to the performances of models in Turkey.

The market, size, value, momentum, liquidity, profitability and investments are ad hoc variables relating average stock returns and the profitability has the highest explanatory power in explanation of average returns. The results obtained from analysis seem striking in some aspects. In FF5 factor model, the profitability is calculated by using operating income item on yearly basis while the q-factor model uses the income from continuing operations item on monthly basis. Since the factor premiums differentiate among the models, both the selection of accounting variable and the calculation frequency could have an effect on factors that help to better capture the common variation of the returns. The maximum squared Sharpe ratio produces the highest value for the $\mathrm{q}$-factor model and right after comes $\mathrm{C} 4$ factor model. These models consist of monthly constructed momentum and profitability factors. That may signify the frequency of portfolio construction matters for the performance of models. 
In other words, the portfolio construction frequency could be crucial in capturing the unexplained returns for the factor models.

For future research, it is considered that the value factor could be constructed monthly or quarterly base.
Since the momentum plays a crucial role on returns, further to investigate how it might affect the performance of new models, the momentum factor could be included in FF5 and the q-factor model.

\section{ENDNOTES}

1 Look-ahead bias born in analysis when the accounting data is used before it was announced to the investors. In other words, unannounced accounting data usage in the analysis as if the investor already had that information.

2 The selection bias is a kind of sampling error that occurs in determining the sample of analysis. In case, the firms that went bankruptcy were excluded from sample that would have caused a spurious view of the sample as if only good firms were performing.

3 For the inference of the formulation, see page 6 the study of the Barillas and Shanken (2017).

4 The eighteen portfolios are abbreviated as SLL, SLM, SLH, SML, SMM, SMH, SHL, SHM, SHH, BLL, BLM, BLH, BML, BMM, $\mathrm{BMH}, \mathrm{BHL}, \mathrm{BHM}, \mathrm{BHH}$. For example, SLL represents the portfolio that consists of small size, low investment and low profitability stocks. 


\section{REFERENCES}

Acaravci, S. K., \& Karaomer, Y. (2017). Fama French five factor model: evidence from Turkey. International Journal of Economics and Financial Issues, 7(6), 130-137.

Aksu, M. H. \& Onder, T. (2003). The size and book-tomarket effects and their role as risk proxies in the Istanbul stock Exchange. (Koc University, Graduate School of Business, Working Paper No. 2000-04). EFMA 2000 Athens.

Arıoğlu, E., \& Canbaş, S. (2008). Testing the three factor model of Fama and French: Evidence from Turkey. Çukurova Üniversitesi Sosyal Bilimler Enstitüsü Dergisi, 17(3), 79-92.

Atakan, T., \& Gökbulut, R. İ. (2010). Üç faktörlü varlık fiyatlandırma nodelinin İstanbul menkul kıymetler borsası'nda uygulanabilirliğinin panel veri analizi ile test edilmesi. Muhasebe ve Finans Dergisi, 45, 180-189.

Amihud, Y. (2002). Illiquidity and stock returns: Cross-section and time-series evidence, Journal of Financial Markets, 5(1), 31-56.

Aras, G., Çam, I., Zavalsız, B., \& Keskin, S. (2018). Fama-French çok faktör varlık fiyatlama modellerinin performanslarının karşılaştırılması: Borsa İstanbul üzerine bir uygulama. Istanbul University Journal of the School of Business Administration, 47(2), 183-207.

Barillas, F., \& Shanken, J. (2017). Which alpha?. The Review of Financial Studies, 30(4), 1316-1338.

Carhart, M. M. (1997). On persistence in mutual fund performance. The Journal of Finance, 52(1), 57-82.

Cooper, I., \& Maio, P. (2019). New evidence on conditional factor models. Journal of Financial and Quantitative Analysis, 54(5), 1975-2016.

Durbin, J., \& Watson, G. S. (1971). Testing for serial correlation in least squares regression. III. Biometrika, 58(1), 1-19.

Erdinç, Y. (2017). Comparison of CAPM, three-factor Fama-French model and five-factor Fama-French model for the Turkish stock market. Financial Management from an Emerging Market Perspective, 69-92.

Fabozzi, F. J., Huang, D., \& Wang, J. (2016). What difference do new factor models make in portfolio allocation?. Available at SSRN 2752822. https://ssrn. com/abstract=2752822, (09.01.2018).

Fama, E. F., \& French, K. R. (1992). The cross section of expected stock returns. The Journal of Finance, 47(2), 427-465.
Fama, E. F., \& French, K. R. (1993). Common risk factors in the returns on stocks and bonds. Journal of Financial Economics, 33(1), 3-56.

Fama, E. F., \& French, K. R. (1995). Size and book to market factors in earnings and returns. The Journal of Finance, 50(1), 131-155.

Fama, E. F., \& French, K. R. (1996). Multifactor explanations of asset pricing anomalies. The Journal of Finance, 51(1), 55-84.

Fama, E. F., \& French, K. R. (2015). A five-factor asset pricing model. Journal of Financial Economics, 116(1), 1-22.

Fama, E. F., \& French, K. R. (2017). International tests of a five-factor asset pricing model. Journal of Financial Economics, 123(3), 441-463.

Gökgöz, F. (2008). Üç faktörlü varlık fiyatlandırma modelinin İstanbul menkul kıymetler borsasında uygulanabilirliği. Ankara Üniversitesi SBF Dergisi. 63 (2), 44-64.

Güzeldere, H., \& Sarıoğlu, S. E. (2012). Varlik fiyatlamada Fama-French üç faktörlü model'in geçerliliği: IMKB üzerine bir araştirma. Business and Economics Research Journal, 3 (2), 1-19.

Hou, K., Xue, C., \& Zhang, L. (2015). Digesting anomalies: An investment approach. The Review of Financial Studies, 28(3), 650-705.

Hou, K., \& Xue, C. (2017). A comparison of new factor models. Fisher College of Business Working Paper, (2015-03), 05.

Jegadeesh, N., \& Titman, S. (1993). Returns to buying winners and selling losers: Implications for stock market efficiency. The Journal of Finance, 48(1), 65-91.

Kang, H., Kang, J., \& Kim, W. (2016). A comparison of new factor models in the Korean stock market. 한국재무햑회 학술대회, 1894-1922.

http://www.korfin.org/korfin_file/forum/ 2016co-conf19-3.pdf, (26.11.2017)

Koh, W. H. (2015). Essays on the cross-section of returns (Doctoral dissertation, The Ohio State University).

Newey, W. K., \& West, K. D. (1987). A simple, positive semi-definite, heteroskedasticity and autocorrelation consistent covariance matrix. Econometrica, 55 (3), 703-708.

Özkan, N . (2019). q-Faktör Modelinin Borsa İstanbul'da geçerliliğinin test edilmesi. Eskişehir Osmangazi Üniversitesi Iktisadi ve Idari Bilimler Dergisi, 14(2), 441-456. 
Pástor, L., \& Stambaugh, R. F. (2003). Liquidity risk and expected stock returns. Journal of Political Economy, 111(3), 642-685.

Unlu, U. (2013). Evidence to support multifactor asset pricing models: The case of the Istanbul stock exchange. Asian Journal of Finance \& Accounting, 5(1), 197.

White, H. (1980). A heteroskedasticity-consistent covariance matrix estimator and a direct test for heteroskedasticity. Econometrica, 48(4), 817-838. 